\title{
Conventional Treatment for Multiple Myeloma Drives Premature Aging Phenotypes and Metabolic Dysfunction in T Cells
}

\author{
Rachel Elizabeth Cooke1,2*, Kylie Margaret Quinn ${ }^{3}$, Hang Quach ${ }^{2,4}$, Simon Harrison ${ }^{2,4}$, \\ Henry Miles Prince ${ }^{2,4}$, Rachel Koldej ${ }^{1,2}$ and David Ritchie ${ }^{1,2,4}$
}

${ }^{1}$ Australian Cancer Research Foundation Translational Research Laboratory, Royal Melbourne Hospital, Melbourne, VIC, Australia, ${ }^{2}$ Department of Medicine, University of Melbourne, Melbourne, VIC, Australia, ${ }^{3}$ School of Health and Biomedical Sciences, RMIT University, Melbourne, VIC, Australia, ${ }^{4}$ Peter MacCallum Cancer Centre, Melbourne, VIC, Australia

OPEN ACCESS

Edited by:

Slavica Vuckovic,

Royal Prince Alfred Hospital, Australia

Reviewed by:

Anne Marit Sponaas, Norwegian University of Science and Technology, Norway Tuna Mutis, Amsterdam University Medical

Center, Netherlands

Taxiarchis Kourelis,

Mayo Clinic, United States

*Correspondence: Rachel Elizabeth Cooke Rachel.Cooke@mh.org.au; rachel.cooke@nh.org.au

Specialty section:

This article was submitted to Cancer Immunity and Immunotherapy, a section of the journal

Frontiers in Immunology

Received: 23 May 2020

Accepted: 07 August 2020 Published: 03 September 2020

Citation:

Cooke RE, Quinn KM, Quach H, Harrison S, Prince HM, Koldej R and

Ritchie D (2020) Conventional

Treatment for Multiple Myeloma Drives Premature Aging Phenotypes and Metabolic Dysfunction in T Cells.

Front. Immunol. 11:2153.

doi: 10.3389/fimmu.2020.02153
New diagnoses of multiple myeloma (MM) tend to occur after the age of 60, by which time thymic output is severely reduced. As a consequence, lymphocyte recovery after lymphopenia-inducing anti-MM therapies relies on homeostatic proliferation of peripheral $T$ cells rather than replenishment by new thymic emigrants. To assess lymphocyte recovery and phenotype in patients with newly diagnosed MM (NDMM) and relapsed/refractory $\mathrm{MM}(\mathrm{RRMM})$, we tracked $\mathrm{CD}^{+}{ }^{+}$and $\mathrm{CD}^{+}{ }^{+} \mathrm{T}$ cell populations at serial time points throughout treatment and compared them to age-matched healthy donors (HD). Anti-MM therapies and autologous stem cell transplant (ASCT) caused a permanent reduction in the CD4:8 ratio, a decrease in naiive $\mathrm{CD}^{+}{ }^{+} \mathrm{T}$ cells, and an increase in effector memory $T$ cells and PD1-expressing CD4 ${ }^{+} T$ cells. Transcriptional profiling highlighted that genes associated with fatty acid $\beta$-oxidation were upregulated in $T$ cells in RRMM, suggesting increased reliance on mitochondrial respiration. High mitochondrial mass was seen in all $T$ cell subsets in RRMM but with relatively suppressed reactive oxygen species and mitochondrial membrane potential, indicating mitochondrial dysfunction. These findings highlight that anti-MM and ASCT therapies perturb the composition of the $T$ cell compartment and drive substantial metabolic remodeling, which may affect the fitness of $T$ cells for immunotherapies. This is particularly pertinent to chimeric antigen receptor (CAR)-T therapy, which might be more efficacious if T cells were stored prior to ASCT rather than at relapse.

Keywords: myeloma, T cell, metabolism, aging, autologous stem cell transplant

\section{INTRODUCTION}

Multiple myeloma (MM) is a malignancy of plasma cells within the bone marrow $(\mathrm{BM})(1,2)$ that is typically diagnosed in patients over the age of 60 years old (3). Treatment for MM has evolved over the last 10 years with the introduction of immune modulatory drugs (IMiDs) and proteasome inhibitors. This has led to a significant increase in life expectancy $(2,4)$, which is most pronounced in patients under 60 years old (5). However, it is notable that the typical age of onset 
for MM coincides with marked decline in immune function during normal biological aging driven by thymic involution and immunosenescence.

From 60 years old, both the number and repertoire diversity of $\mathrm{T}_{\mathrm{N}}$ cells declines substantially due to a process known as thymic involution $(6,7)$. Thymic involution refers to a loss of thymic stromal tissue and function, which limits de novo production of naïve $\mathrm{T}\left(\mathrm{T}_{\mathrm{N}}\right)$ cells. With this decline in de novo $\mathrm{T}_{\mathrm{N}}$ cell production, homeostatic proliferation of peripheral $\mathrm{T}$ cells appears to compensate and increases with age (8). As a result, in the event of a sudden decline in the number of lymphocytes (such as might occur during high dose chemotherapy), the aged thymus has limited capacity for $\mathrm{T}_{\mathrm{N}}$ cell output $(9,10)$. Instead, repopulation of the peripheral $\mathrm{T}$ cell population is predominantly driven by lymphopenia-induced proliferation, mediated by the increased availability of $\gamma c$ cytokines, such as IL-7 and IL-15. Lymphopenia-induced proliferation favors expansion of $\mathrm{CD}^{+}$memory $\mathrm{T}$ cells, because $\mathrm{CD}^{+}$memory $\mathrm{T}$ cells express higher levels of a component of the IL-15 receptor (CD122) (11) and $\mathrm{CD}^{+}{ }^{+} \mathrm{T}$ cell homeostatic expansion is limited by IL-7-dependent STAT-1 activation (12). More recently, signaling from $\gamma c$ cytokines has been seen to drive metabolic remodeling in $\mathrm{T}$ cells in mouse models of aging, inflammation, and lymphopenia (13-15), but the impact of lymphopeniainducing therapies on $\mathrm{T}$ cell metabolism in aged humans has not been defined.

Immunosenescence refers to a loss of intrinsic function in immune cells, which can undermine responses to vaccines, infections, and cancer (16). Chronic age-related inflammation and metabolic stress are thought to be significant drivers of immunosenescence for a variety of immune cells, including $\mathrm{CD}^{+}$and $\mathrm{CD}^{+} \mathrm{T}$ cells $(17,18)$. During $\mathrm{MM}$ disease, it is well established that MM cells can create a microenvironment of chronic inflammation in the BM, characterized by increased production of IL-6 in particular (19). IL-6 sustains tumor survival, but it also drives production of senescent cells that exhibit a senescence-associated secretory phenotype $(20,21)$, all of which are predicted to augment dysfunction in $\mathrm{CD}_{4}^{+}$ and $\mathrm{CD}^{+} \mathrm{T}$ cells. Inflammation-associated cytokine stimulation is also known to drive metabolic changes in a variety of immune cells, including $\mathrm{T}$ cells (13-15). Given the complex relationship between $\mathrm{T}$ cell homeostasis, inflammation, and aging, understanding the shifts in the immune system that result from normal aging, MM disease and MM therapies will be critical for implementing immune therapies in MM patients (22).

Previously, we demonstrated a loss of $\mathrm{T}_{\mathrm{N}}$ cells in the peripheral blood (PB) of MM patients, with a reciprocal expansion of effector memory $\left(\mathrm{T}_{E M}\right)$ cells $(23)$. In the $\mathrm{CD}^{+} \mathrm{T}$ cell population, a loss of $\mathrm{T}_{\mathrm{N}}$ cells is already observed at diagnosis and is equivalent to the loss of $\mathrm{T}_{\mathrm{N}}$ cells seen in elderly healthy donors (HD). In contrast, in the $\mathrm{CD}^{+} \mathrm{T}$ cell population, $\mathrm{T}_{\mathrm{N}}$ cells are relatively preserved in the elderly and newly diagnosed MM (NDMM), with significant loss of $\mathrm{T}_{\mathrm{N}}$ cells only observed in relapsed/refractory MM (RRMM) (24). This also leads to a decrease in CD4:8 ratio, which is a characteristic finding in MM with disease progression $(23,25)$. While prior studies of patients with NDMM and RRMM concluded that changes in NK and
T cell populations were corticosteroid-induced and/or diseasedriven $(23,24,26-28)$, autologous stem cell transplant (ASCT) and $\mathrm{T}$ cell-depleting therapies form the backbone of treatment for medically fit MM patients, and their long-term impact on $\mathrm{T}$ cell function has not been well-described.

In this study, we demonstrate that ASCT and/or MM disease does irreversibly change the composition of $\mathrm{T}$ cell populations, with a dramatic loss of $\mathrm{CD} 4^{+} \mathrm{T}_{\mathrm{N}}$ cells and reciprocal increase in $\mathrm{CD}^{+}$effector memory $\mathrm{T}$ cells, and an increase in PD1-expressing $\mathrm{CD}^{+} \mathrm{T}$ cells. We also observe metabolic changes in $\mathrm{T}$ cells from RRMM patients, with increased expression of transcripts for mitochondrial respiration, increased mitochondrial load, and decreased reactive oxygen species (ROS), which suggests a loss of metabolic fitness. We propose a model where ASCT and/or MM disease-derived inflammation drives increased inflammatory and $\gamma$ c cytokine signaling and lymphopenia-induced proliferation and accelerated immunosenescence, which would mediate the dramatic loss of $\mathrm{T}_{\mathrm{N}}$ cells in $\mathrm{MM}$ patients and metabolic remodeling in the remaining $\mathrm{T}$ cells. These findings inform our current treatment protocols for MM and will guide integration of new immunebased therapies for MM. While lymphopenia may drive $\mathrm{CD} 4^{+}$ $\mathrm{T}_{\mathrm{N}}$ cell loss, we may be able to intervene with dendritic cell (DC) vaccination, checkpoint blockade, or metabolic interventions during post-ASCT lymphopenia to better support the recovering $\mathrm{T}$ cell population. Furthermore, the collection of T cells prior to ASCT (as opposed to at the time of relapse) would likely provide a more efficacious chimeric antigen receptor (CAR)-T product.

\section{MATERIALS AND METHODS}

\section{Human Samples and Cells}

All research was conducted in full compliance with principles of the "Declaration of Helsinki," Good Clinical Practice, and within the laws and regulations of Australia. Cryopreserved peripheral blood mononuclear cells (PBMCs) were analyzed from MM patients enrolled on two historical clinical trials: LITVACC (ACTRN12613000344796) that recruited NDMM patients and REVLITE (NCT00482261) that recruited RRMM patients, which are illustrated in Figure 1A.

Newly diagnosed MM patients received four induction cycles of lenalidomide and dexamethasone (LEN/DEX) followed by ASCT, and they were then partitioned into one of two study arms, with either (i) monthly DC vaccines + LEN or (ii) LEN \pm DEX maintenance therapy. Both study arms have been combined in this analysis as sample numbers were underpowered to detect any small variances. Paired patient PBMC samples (where available) were analyzed at three consecutive time points: cycle 4 of induction (Pre-ASCT, $n=29$ ), at maintenance cycle 4 after ASCT (Post-ASCT, $n=21$ ), and at last follow-up [end of treatment (EOT), $n=21$ ]. The mean time to last follow-up was well over 2 years at 1069 days (range: 397-1780 days), to ensure maximal peripheral leukocyte reconstitution.

Relapsed/refractory MM patients were also treated with successive cycles of LEN/DEX and evaluated for stable disease, and for those who had stable disease, we analyzed PBMC samples 


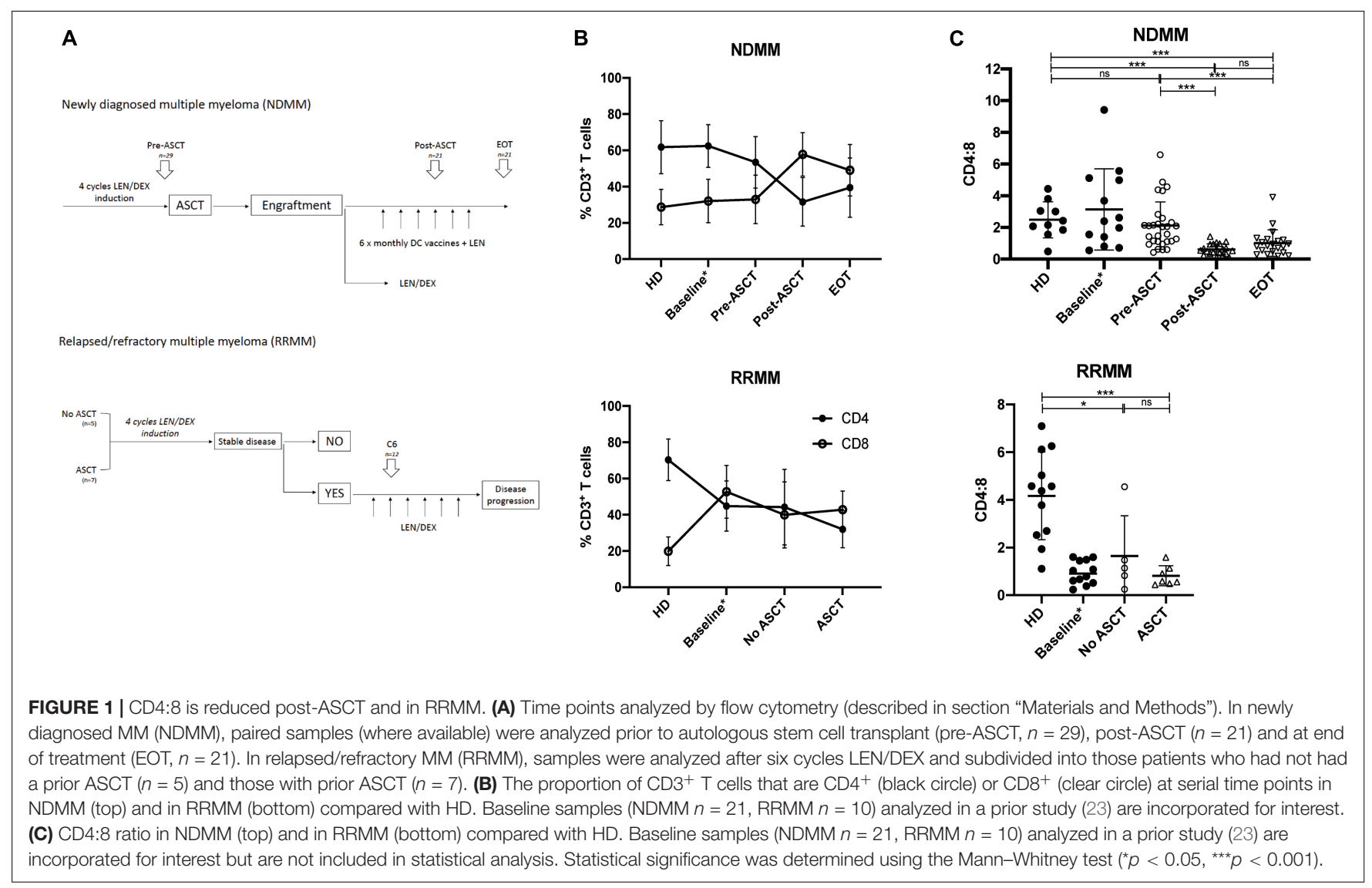

after six cycles of LEN/DEX. We retrospectively subdivided this group for analysis into those patients who had not received prior ASCT (No ASCT, $n=5$ ) and those who had (ASCT, $n=7$ ).

Peripheral blood mononuclear cells from age-matched HD were used as a control group and were collected via the Australian Red Cross Blood Service and the Victorian Blood Donor Registry.

\section{T Cell Flow Cytometric Analysis}

Flow cytometry was performed using Fixable viability stain 700 (BD Horizon) and directly conjugated anti-human antibodies: CD3 (SK7, BD Biosciences), CD4 (RPA-T4, BD Pharmingen or SK3, BD Horizon), CD8 (RPA-T8, BD Pharmingen), CD45RA (H100, eBiosciences), CD197 (CCR7) (3D12, eBiosciences) and CD279 (PD1) (EH12, BD Horizon). Cell surface staining was performed with $5 \times 10^{6}$ to $1 \times 10^{7}$ PBMCs in a $100-\mu 1$ cell suspension of FACS buffer and antibody master mix for $30 \mathrm{~min}$ at $4^{\circ} \mathrm{C}$. Cells were washed and resuspended in FACS buffer or complete RPMI containing mitochondrial fluorescent dyes for mitochondrial assessment. Lymphocytes were gated using forward and side scatter, followed by doublet and dead cell removal. BD Anti-Mouse or Anti-Goat Comp Beads were used to optimize fluorescence compensation settings for analysis. Fluorescence minus one (FMO) controls were used to assist with gating. Analysis was performed on a BD LSR Fortessa and analyzed using FlowJo software (Version 10). $\mathrm{T}$ cell differentiation subsets were defined as the following:
Naïve (TN): $\mathrm{CD} 3+\mathrm{CD} 4+/ 8^{+} \mathrm{CD} 45 \mathrm{RA}^{+} \mathrm{CCR}^{+}$, central memory $\left(\mathrm{T}_{\mathrm{CM}}\right): \mathrm{CD}^{+} \mathrm{CD}^{+} / 8^{+} \mathrm{CD} 4 \mathrm{RA}{ }^{-} \mathrm{CCR}^{+}$, effector memory $\left(\mathrm{T}_{\mathrm{EM}}\right): \mathrm{CD}^{+} \mathrm{CD}^{+} / 8^{+} \mathrm{CD} 45 \mathrm{RA}^{-} \mathrm{CCR}^{-}$, and effector memory $\mathrm{CD}_{45 \mathrm{RA}^{+}}\left(\mathrm{T}_{\mathrm{EMRA}}\right): \mathrm{CD}^{+} \mathrm{CD}^{+} / 8^{+} \mathrm{CD} 45 \mathrm{RA}^{+} \mathrm{CCR}^{-}$.

\section{RNA Sequencing}

$\mathrm{CD}^{+} \mathrm{T}$ cells were enriched from PBMCs using the MACS ${ }^{\circledR}$ human $\mathrm{CD}^{+} \mathrm{T}$ cell isolation kit, as per the manufacturer's instructions. $\mathrm{CD} 4{ }^{+} \mathrm{T}$ cell purity was $>80 \%$. RNA was extracted with Trizol, and cDNA library creation and RNA sequencing were performed by the Australian Genome Research Facility at the Walter and Eliza Hall Institute. Because there was significant RNA degradation in the sample set, the SMARTer Stranded Total RNA-Seq Kit-Pico Input Mammalian (Takara Bio USA) protocol was used, which incorporates a ribosomal RNA depletion. Genes needed to pass a 20 read threshold in $>80 \%$ of samples in order to be analyzed. Bioinformatic analysis was performed at Melbourne Bioinformatics, University of Melbourne, utilizing the Limma linear model (29).

\section{Real-Time qPCR}

$\mathrm{CD}^{+}{ }^{+}$and $\mathrm{CD}^{+}{ }^{+} \mathrm{T}$ cells were enriched from PBMCs using the $\mathrm{MACS}^{\circledR}$ human $\mathrm{CD}^{+} \mathrm{T}$ cell isolation kit or $\mathrm{MACS}^{\circledR}$ human $\mathrm{CD}^{+}$Microbeads (Miltenyi Biotec), as per the manufacturer's instructions. RNA was extracted with Trizol and cDNA was synthesized using the Superscript VILO cDNA kit (Thermo 
Fisher Scientific), as per the manufacturer's instructions. Target genes were analyzed using TaqMan gene expression assays with TaqMan Fast Universal master mix on the QuantStudio 7 Flex Real-Time PCR system (Thermo Fisher Scientific), as per the manufacturer's instructions. The housekeeping gene TBP was used as the endogenous control to calculate relative gene expression.

\section{Mitochondrial Staining}

After cell surface staining, cells were incubated at $37^{\circ} \mathrm{C}$ for $30 \mathrm{~min}$ in complete RPMI containing mitochondrial fluorescent dyes (Thermo Fisher Scientific), using a combination of MitoTracker deep red FM (MTdr) at 1:20,000 and either CellRox ${ }^{\circledR}$ Orange reagent (CellRoxO) at 1:1000 or tetramethylrhodamine, methyl ester (TMRM) at 1:3000. Cell suspensions were washed and resuspended in $\mathrm{T}$ cell media for flow cytometric analysis.

\section{Statistical Analysis}

Data were analyzed using GraphPad Prism software (version 7).

\section{RESULTS}

\section{Phenotypic Changes in the Composition of T Cell Subsets}

To track changes in $\mathrm{T}$ cell populations throughout the course of MM disease and treatment, we analyzed PBMCs from patients with NDMM and RRMM collected at serial time points throughout their treatment and compared with agematched HD. Study design and analysis time points are described in section "Materials and Methods" and in Figure 1A, and patient characteristics are shown in Supplementary Tables 1, 2. Unfortunately, baseline samples from patients prior to any treatment were not available for this analysis, but they have been described in previous work (23), which we include for interest but do not include in statistical analysis as these are not matched samples and it should be noted that different fluorochromes and gating strategies were used in the prior analysis.

In NDMM, the CD4:8 ratio was similar to $\mathrm{HD}$ in patients at baseline and pre-ASCT after four induction cycles of LEN/DEX, but it was significantly reduced post-ASCT and did not recover to baseline by EOT (Figures 1B,C, left). Prolonged $\mathrm{CD}^{+} \mathrm{T}$ cell depletion has been described after ASCT in children and young adults (10), but the CD4:8 ratio recovers to baseline levels by 1 year post-ASCT (30). Our results in an older population differ in this regard, and support findings by Chung et al. (30), who also demonstrated a reduction in the CD4:8 ratio in MM patients after ASCT up to 1 year post-ASCT. Subanalysis of the population that received DC vaccines $(n=8)$ suggested a trend toward expansion of the $\mathrm{CD} 8^{+} \mathrm{T}$ cell population (and further reduction of CD4:8) compared with those receiving LEN/DEX therapy $(n=13)$ at the post-ASCT time point; however, this did not reach statistical significance and was indistinguishable by EOT (Supplementary Figure 1).
In RRMM (at baseline and after LEN/DEX treatment, irrespective of prior ASCT), the CD4:8 ratio was also significantly reduced compared with $\mathrm{HD}$ (Figures 1B,C, right), although we note that the mean CD4:8 ratio in the this $\mathrm{HD}$ group is higher than that used for the NDMM comparison that may reflect heterogeneity in the normal population and/or minor differences in the fluorochromes used. The CD4:8 ratio is likely reduced in RRMM patients as a whole as they were probably treated previously with cyclophosphamide (commonly used in induction regimens in Australia), which is known to induce lymphopenia.

We next observed the differentiation status of $\mathrm{CD}^{+}$and $\mathrm{CD}^{+} \mathrm{T}$ cell populations over the course of treatment. In NDMM pre-ACST, phenotypic composition was similar to HD, but postASCT, there was a significant decrease in the proportion of $\mathrm{CD}^{+}$that were $\mathrm{T}_{\mathrm{N}}$ and $\mathrm{T}_{\mathrm{CM}}$ cells and a reciprocal increase in $\mathrm{T}_{\mathrm{EM}}$ cells, which persisted to EOT (Figures 2A,B, left). In RRMM (at baseline and with treatment), there was also a significant decrease in the proportion of $\mathrm{CD}^{+} \mathrm{T}_{\mathrm{N}}$ cells but, unlike in NDMM, both the $\mathrm{CD}^{+} \mathrm{T}_{\mathrm{CM}}$ and $\mathrm{T}_{\mathrm{EM}}$ populations had reciprocally expanded (Figure 2C, left). These shifts in phenotypic composition were not evident in $\mathrm{CD}^{+} \mathrm{T}$ cells, because $\mathrm{T}_{\mathrm{EMRA}}$ cells are already an established subset in older HD (Figures 2B,C, right).

\section{There Are Temporal and Compartmental Differences in PD-1 Expression Between $\mathrm{CD}^{+}$and $\mathrm{CD}^{+}{ }^{+}$Cells}

In the $\mathrm{Vk}^{*} \mathrm{MYC}$ murine model of $\mathrm{MM}, \mathrm{PD} 1$ expression was shown to transiently increase on $\mathrm{T}$ cells 30 days posttransplant (31). PD-L1 blockade also increased the efficacy of hematopoietic stem cell transplant, adoptive $\mathrm{T}$ cell transfer, and a post-transplant DC vaccine (31), and increased survival when administered during the homeostatic proliferation phase after non-myeloablative total body irradiation (32). This suggests that PD1/PD-L1 monoclonal antibodies may be beneficial postASCT, but human studies have not demonstrated significantly altered PD1 expression post-ASCT (30). We wanted to further dissect PD1 expression in $\mathrm{CD}^{+}$and $\mathrm{CD}^{+} \mathrm{T}$ cell subsets during MM treatment.

In $\mathrm{CD} 4^{+} \mathrm{T}$ cells, the proportion expressing PD1 was increased in both NDMM and RRMM patients compared with HD and was highest post-ASCT in NDMM (Figures 3B,C, left). In CD8 ${ }^{+}$ $\mathrm{T}$ cells, there was no statistically significant change but there did appear to be two populations post-ASCT: one with and one without PD1 expression (Figures 3B,C, right). Subanalysis shows a trend toward increased $\% \mathrm{PD}^{+}$in the group receiving DC vaccine but this does not reach statistical significance (Supplementary Figure 3). PD1 expression remained high in $\mathrm{CD}^{+} \mathrm{T}$ cells at EOT, while it returned to normal in $\mathrm{CD}^{+}$ $\mathrm{T}$ cells (Figure 3B). The latter finding was also described in the post-allogeneic stem cell transplant setting, where PD1 facilitated apoptosis of alloreactive $\mathrm{CD}^{+} \mathrm{T}$ cells by increasing ROS (33).

$\mathrm{PD}^{+}$events were then backgated to define the phenotypic distribution of PD1 expression (Supplementary Figure 2). 
A

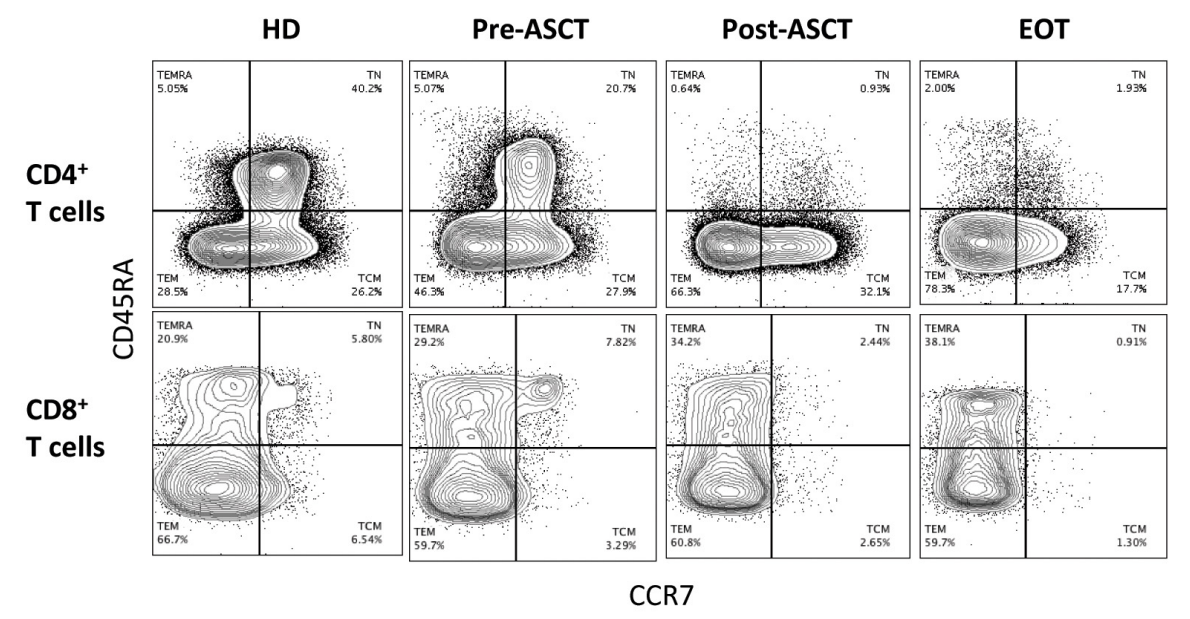

B
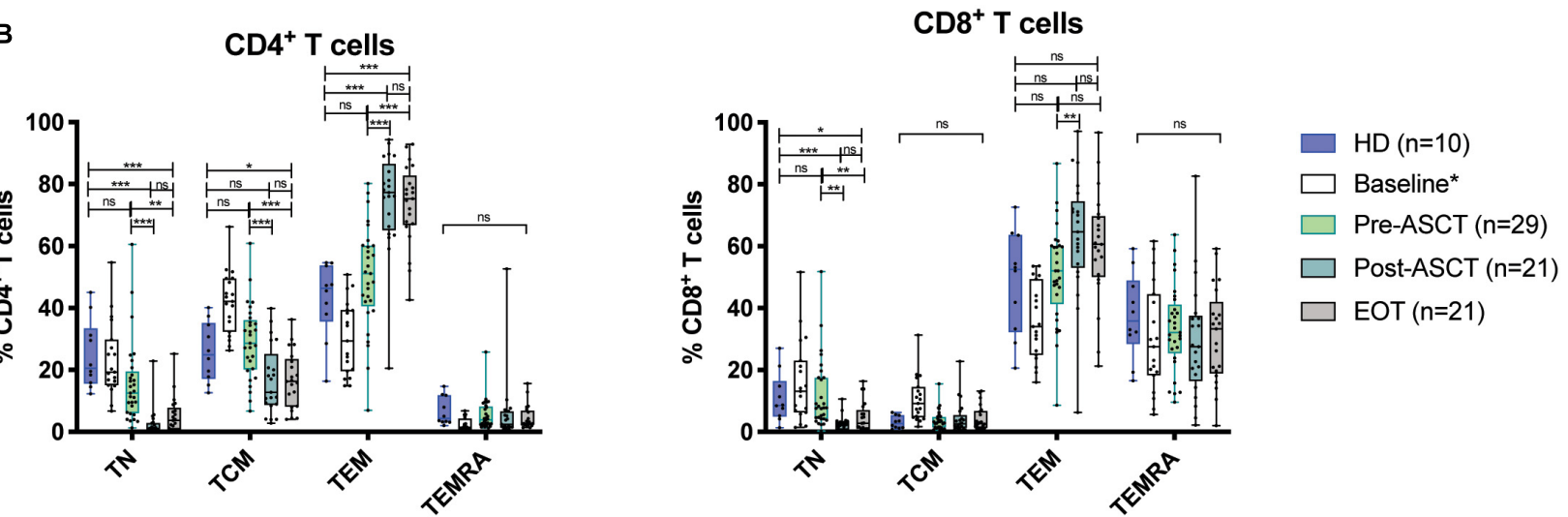

C
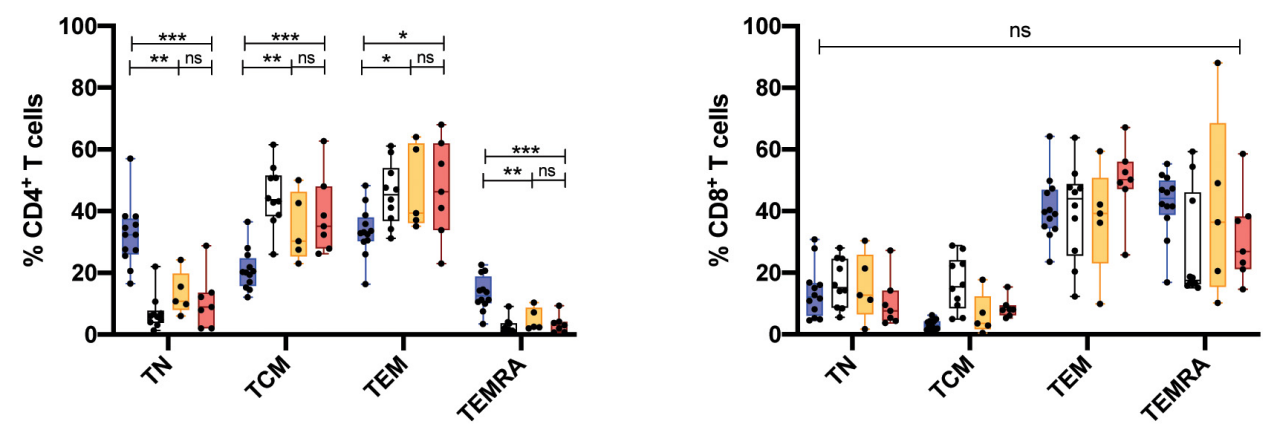

HD $(n=12)$

$\square$ Baseline* $^{*}$

$\square$ RRMM (no ASCT, n=5)

$\square \operatorname{RRMM}(\mathrm{ASCT}, \mathrm{n}=7)$

FIGURE 2 | Phenotypic composition of T cell populations with MM. (A) Representative flow plots of $\mathrm{CD}^{+}$and $\mathrm{CD} 8^{+} \mathrm{T}$ cells from serial time points in NDMM samples, defining $T_{N}, T_{C M}, T_{E M}$, and $T_{E M R A}$ subsets. (B,C) The proportion of $\mathrm{CD}^{+}$(left) and $\mathrm{CD} 8^{+}$(right) $\mathrm{T}$ cells of each phenotype subsets at serial time points in (B) NDMM and (C) RRMM patient samples. Baseline samples analyzed in a prior study (23) are incorporated for interest but are not included in statistical analysis. Statistical significance was determined using multiple Student's $t$-tests with the Holm-Sidak method applied $\left({ }^{\star} p<0.05,{ }^{* *} p<0.01\right.$, $\left.{ }^{* \star *} p<0.001\right)$.

In $\mathrm{HD}$, most $\mathrm{PD}^{+}$cells were $\mathrm{T}_{\mathrm{EM}}$ phenotype, with minor proportions of $\mathrm{T}_{\mathrm{N}}, \mathrm{T}_{\mathrm{CM}}$, and $\mathrm{T}_{\mathrm{EMRA}}$ phenotypes; however, there were significant proportions of $\mathrm{T}_{\mathrm{CM}}$ and $\mathrm{T}_{\mathrm{EMRA}}$ in $\mathrm{CD} 4^{+}$and $\mathrm{CD} 8^{+} \mathrm{PD}^{+}$populations, respectively. We then assessed PD1 expression in $\mathrm{T}$ cell differentiation subsets (Figure 3D). In $\mathrm{CD} 4^{+}$
$\mathrm{T}$ cells, the proportion of $\mathrm{T}_{\mathrm{N}}, \mathrm{T}_{\mathrm{CM}}$, and $\mathrm{T}_{\mathrm{EMRA}}$ that were $\mathrm{PD} 1^{+}$ increased significantly in NDMM post-ASCT and in RRMM with prior ASCT, compared with HD (Figures 3E,F, left). The proportion of $\mathrm{CD} 4^{+} \mathrm{T}_{\mathrm{CM}}$ that were $\mathrm{PD} 1^{+}$also remained elevated at EOT in NDMM. In CD8 T cell subsets, differences in PD1 


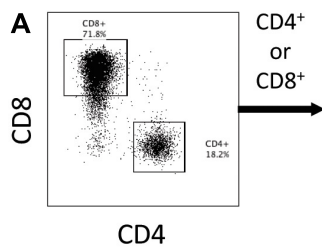

B

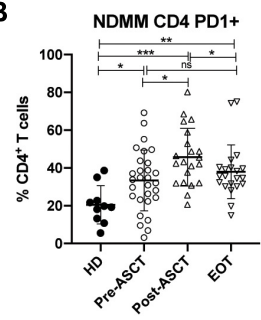

C

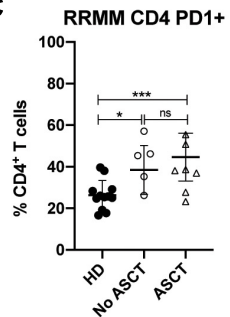

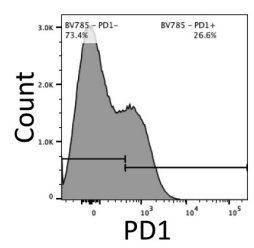
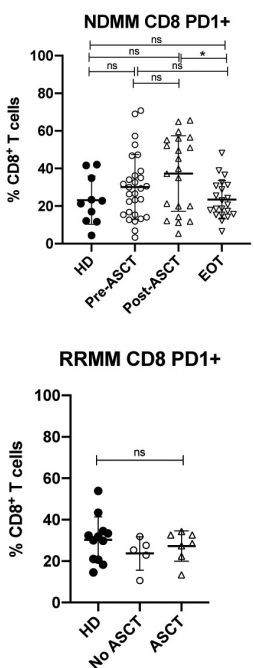
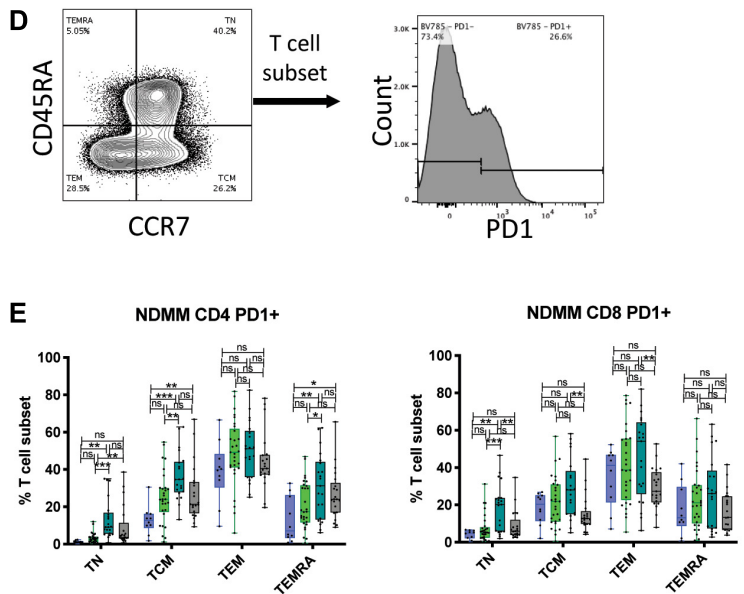

- $\mathrm{HD}(\mathrm{n}=10)$

Pre-ASCT (n=29)

Post-ASCT ( $\mathrm{n}=21)$

$\square$ EOT (n=21)

FIGURE 3 | PD1 expression on T cell subsets after ASCT. (A-C) PD1 expression in CD4 ${ }^{+}$and CD8 ${ }^{+}$T cells. (A) Representative gating strategy. (B,C) Scatter plots showing PD1 ${ }^{+}$events as\% of CD4 ${ }^{+}$T cells (left) and CD8 ${ }^{+}$T cells (right) in (B) NDMM at serial time points and (C) RRMM, compared to HD. Statistical significance was determined using the Mann-Whitney test $\left({ }^{\star} p<0.05,{ }^{* \star} p<0.01,{ }^{\star \star \star} p<0.001\right)$. (D-F) PD1 expression in T cell differentiation subsets. (D) Representative gating strategy. (E,F) Box and whisker plots showing PD1 ${ }^{+}$events as \% of T cell subset $\left(T_{N}, T_{C M}, T_{E M}\right.$, and $\left.T_{E M R A}\right)$ for CD4 ${ }^{+} T$ cells (left) and CD8 ${ }^{+} T$ cells (right) in (E) NDMM at serial time points and (F) RRMM, compared to HD. Statistical significance was determined using the Student's $t$-test with the Holm-Sidak method applied $\left({ }^{\star} p<0.05,{ }^{\star \star} p<0.01,{ }^{\star \star *} p<0.001\right)$.

expression were modest (Figures 3E,F, right), in keeping with prior observations (30).

\section{Fatty Acid $\beta$-Oxidation Is Increased in T Cells From RRMM Compared With HD}

$\mathrm{T}$ cell function and survival are supported by the selective use of distinct metabolic pathways (34-36). For example, effector $\mathrm{T}$ cell activation and proliferation is supported by a shift toward aerobic glycolysis, while memory $\mathrm{T}$ cells utilize fatty acid oxidation (FAO) to fuel mitochondrial respiration. Furthermore, as previously mentioned, animal models demonstrate that aging, inflammation, and lymphopenia can all alter the metabolic capacity of $\mathrm{T}$ cells to promote mitochondrial respiration (13-15).

We performed preliminary RNA-Seq analysis on $\mathrm{CD}^{+} \mathrm{T}$ cells from $\operatorname{HD}(n=2)$ and $\operatorname{RRMM}(n=2)$ samples to identify differentially expressed genes (DEGs). When lists of DEGs were interrogated for significant enrichment of specific biological pathways in the KEGG databases, the top upregulated pathways included RAP1, PI3K-AKT, cAMP, calcium, and PPAR signaling pathways (Supplementary Figure 4), which can augment specific metabolic responses, particularly in relation to FAO and mitochondrial respiration.
To further explore this, we evaluated the expression of key genes for glycolysis and FAO (Table 1) in $\mathrm{CD}^{+}$and $\mathrm{CD}^{+}$ $\mathrm{T}$ cells with a larger cohort of RRMM and HD samples by using quantitative PCR; sample characteristics are described in Supplementary Table 3. There was no difference in relative RNA quantitation (RQ) between RRMM and HD for nearly all of the glycolysis genes analyzed; the one exception was PKM (pyruvate kinase), which was increased in RRMM compared with $\mathrm{HD}$ (Figure 4A). While pyruvate kinase is in the glycolytic pathway, it generates pyruvate that can either undergo aerobic glycolysis or be converted into acetyl CoA to provide substrate for mitochondrial respiration. In contrast, the expression of nearly all of the FAO genes were significantly higher in both $\mathrm{CD} 4^{+}$ and $\mathrm{CD}^{+} \mathrm{T}$ cells in RRMM compared to HD (Figure 4B). These results suggest that FAO and mitochondrial respiration is upregulated in T cells in RRMM compared with HD.

\section{Mitochondrial Mass Is Significantly Increased in T Cell in RRMM}

Given that genes associated with FAO and mitochondrial respiration were upregulated in $\mathrm{T}$ cells in RRMM, we then assessed mitochondrial mass using the MitoTracker ${ }^{\mathrm{TM}}$ Deep Red FM dye (MTdr). MTdr staining was significantly increased in 
TABLE 1 | Genes analyzed by qPCR to assess glycolysis and fatty acid $\beta$-oxidation in T cells.

\begin{tabular}{|c|c|c|c|}
\hline Mode of metabolism & Gene & Abbreviation & Function \\
\hline \multirow[t]{3}{*}{ Glycolysis } & Hexokinase 1 & HK1 & $\begin{array}{l}\text { Hexokinases phosphorylate glucose to produce glucose-6-phosphate, the first } \\
\text { step of glycolysis. This gene encodes a ubiquitous form that localizes to the } \\
\text { outer membrane of mitochondria. }\end{array}$ \\
\hline & Pyruvate kinase, muscle & $\mathrm{PKM}$ & $\begin{array}{l}\text { Enzyme involved in the production of pyruvate that can either undergo aerobic } \\
\text { glycolysis or be converted to acetyl COA (a substrate of the TCA cycle) }\end{array}$ \\
\hline & $\begin{array}{l}\text { Lactate dehydrogenase, } \mathrm{A} \text { and } \\
\text { B subunits }\end{array}$ & LDHA, LDHB & $\begin{array}{l}\text { Catalyze the interconversion of pyruvate and lactate in the last step of aerobic } \\
\text { glycolysis }\end{array}$ \\
\hline \multirow[t]{3}{*}{ Fatty acid $\beta$-oxidation } & $\begin{array}{l}\text { Carnitine palmitoyl transferase } \\
1 \mathrm{~A}\end{array}$ & CPT1A & $\begin{array}{l}\text { Rate-limiting enzyme in the transport of fatty acids across the mitochondrial } \\
\text { inner membrane }\end{array}$ \\
\hline & $\begin{array}{l}\text { Acyl-CoA dehydrogenase, very } \\
\text { long chain }\end{array}$ & ACADVL & Catalyzes the first step of the mitochondrial fatty acid $\beta$-oxidation pathway \\
\hline & Acetyl-CoA acyltransferase 2 & AACA2 & Catalyzes the last step of the mitochondrial fatty acid $\beta$-oxidation pathway \\
\hline
\end{tabular}

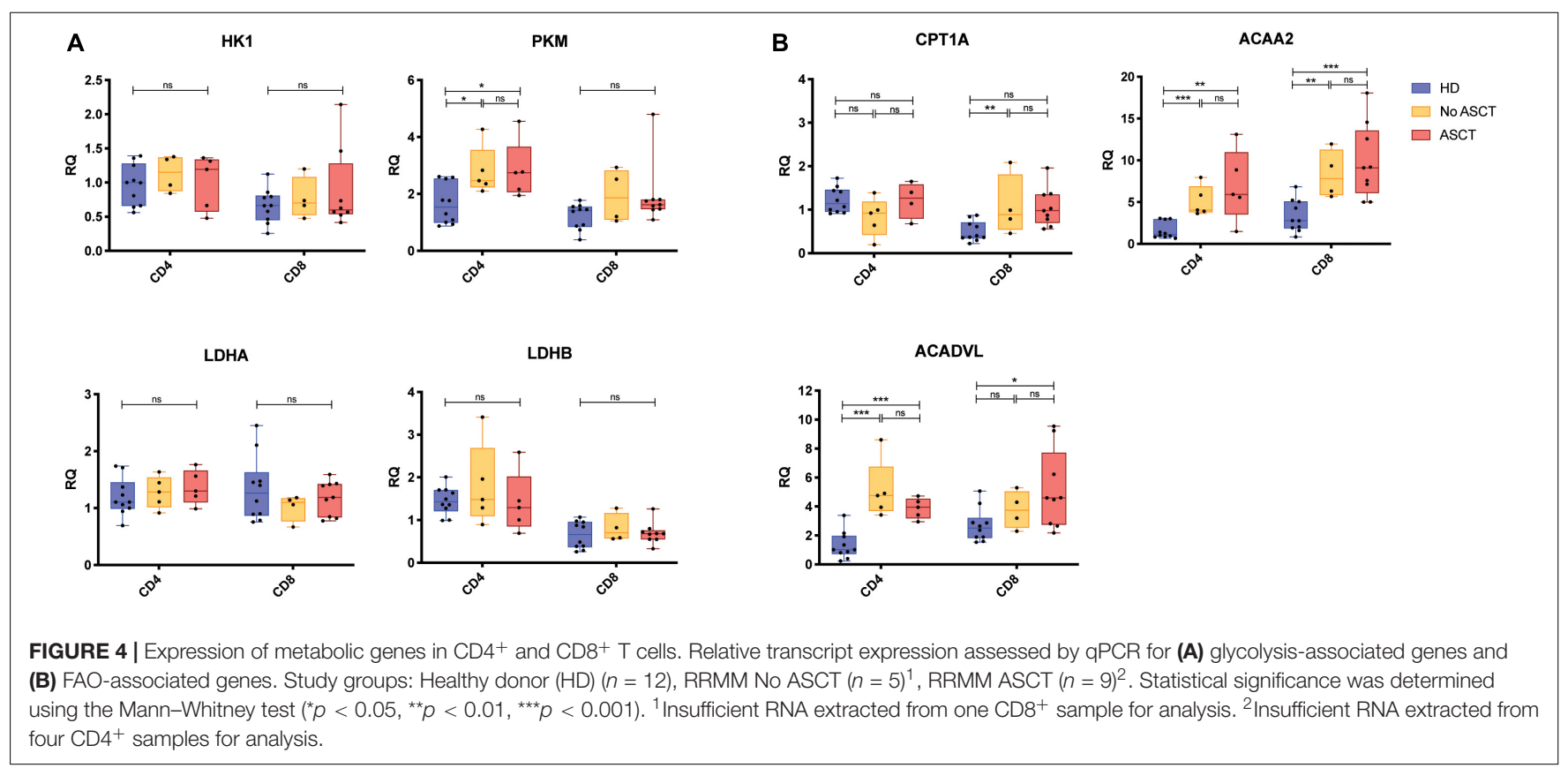

both $\mathrm{CD}^{+}$and $\mathrm{CD}^{+}{ }^{+} \mathrm{T}$ cells from RRMM patients compared with HD (Figure 5A); in fact, virtually all $\mathrm{T}$ cells had high MTdr expression, unlike HD, where T cells were predominantly MTdr low-intermediate or MTdr negative (Figure 5B). This increase in MTdr staining was seen across all $\mathrm{T}$ cell subsets in RRMM (Figure $5 \mathrm{C}$ ), but it was most marked in $\mathrm{T}_{\mathrm{N}}$ and $\mathrm{T}_{\mathrm{CM}}$ cells (Figure 5D).

\section{Mitochondrial ROS Levels Are Reduced in T Cells in RRMM}

$\mathrm{CD}^{+}$and $\mathrm{CD}^{+}{ }^{+} \mathrm{T}$ cells in RRMM had elevated mitochondrial mass, but these mitochondria may not necessarily be functional. To assess the functionality of mitochondria, we then measured ROS, which are produced during normal mitochondrial respiration, using the CellROX Orange dye. We gated on cells with high mitochondrial mass for internal consistency (Figure 6A) and saw that both $\mathrm{CD}^{+}$and $\mathrm{CD}^{+} \mathrm{T}$ cells from RRMM patients showed significantly lower ROS levels than
HD (Figure 6B). This reduction in ROS levels was evident across all $\mathrm{T}$ cell populations (Figure 6C). In HD, ROS levels were highest in $\mathrm{T}_{\mathrm{CM}}$ and $\mathrm{T}_{\mathrm{EM}}$ cells, which would be expected as these cells rely more heavily on mitochondrial respiration to meet their energy demands, but in RRMM, this difference was reduced (Figure 6D).

\section{Mitochondrial Membrane Potential $(\Delta \psi \mathrm{m})$ Is Increased in CD4 ${ }^{+} \mathrm{T}_{\mathrm{CM}}$ Cells in RRMM}

High mitochondrial mass accompanied by low ROS levels is suggestive of reduced mitochondrial activity. To assess whether mitochondria were still functional, we assessed mitochondrial membrane potential $(\Delta \psi \mathrm{m})$ using the tetramethylrhodamine, methyl ester dye (TMRM), which is retained in mitochondria with intact membrane potential. We again gated on cells with high mitochondrial mass for internal consistency and saw that $\Delta \psi \mathrm{m}$ was significantly higher in the $\mathrm{CD} 4^{+} \mathrm{T}$ cells from RRMM 

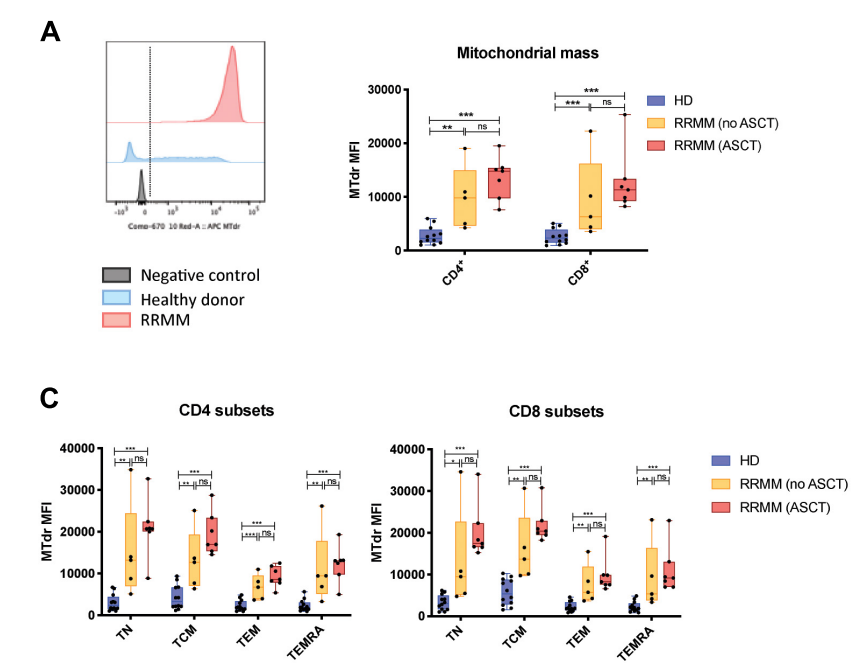

B

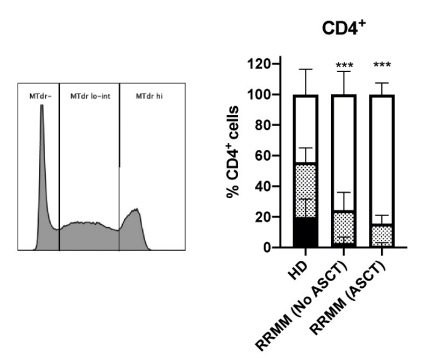

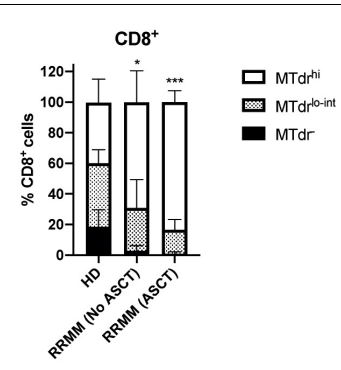

D

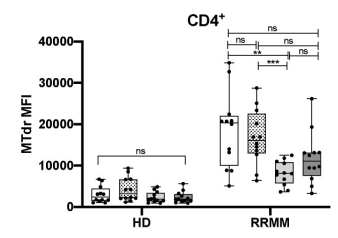

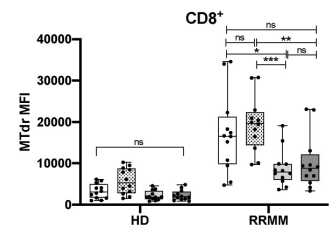

$\square$ TN

$\square$ TEM

FIGURE 5 | Mitochondrial mass in RRMM. (A) Mitochondrial mass measured by geometric mean fluorescence intensity (MFI) of MitoTracker Deep Red (MTdr) in $\mathrm{CD}^{+}$and $\mathrm{CD}^{+} \mathrm{T}$ cells from healthy donors and RRMM. Representative histograms (left) and box and whisker plots (right). (B) Proportion of CD4/8 T cells with high $\left(\mathrm{MTdr}^{\text {hi }}\right)$, low-intermediate (Mtdrlo-int), and absent (MTdr-) mitochondrial mass by MFI. Representative histogram (left) and stacked bar charts (right). (C,D) Box and whisker plots showing mitochondrial mass by MFI in CD4 ${ }^{+}$and CD8 ${ }^{+}$T cell subsets from RRMM and HD by (C) treatment group or by (D) T cell subset (with no ASCT and ASCT combined for RRMM). Study groups as described in Figure 1. Statistical significance in all figures was determined using multiple Student's $t$ tests with the Holm-Sidak method applied $\left({ }^{\star} p<0.05,{ }^{\star \star} p<0.01,{ }^{\star \star *} p<0.001\right)$.

patients compared to HD, but there was no significant difference for $\mathrm{CD}^{+} \mathrm{T}$ cells (Figure 7A). The RRMM population appeared to be bimodal and, to compare the phenotypic composition of these two subpopulations, we back-gated TMRM ${ }^{-}$and $\mathrm{TMRM}^{+}$ events (Figure 7B, left). A high proportion of $\mathrm{TMRM}^{+} \mathrm{T}$ cells were $\mathrm{T}_{\mathrm{CM}}$ phenotype, particularly within the $\mathrm{CD} 4^{+} \mathrm{T}$ cell population (Figure $7 \mathbf{B}$, right), suggesting that $\mathrm{T}_{\mathrm{CM}}$ cells are the most metabolically active subset.

\section{DISCUSSION}

Autologous stem cell transplant remains a backbone of MM treatment in medically fit patients, but our findings suggest that ASCT and lymphopenia-inducing therapies in MM have a largely irrecoverable effect on the $\mathrm{CD} 4^{+} \mathrm{T}$ cell population. We illustrate that these therapies contribute toward a reduction in the CD4:8 ratio (Figure 1) and $\mathrm{CD}^{+} \mathrm{T}_{\mathrm{N}}$ cells (Figure 2), with a skewing of the $\mathrm{T}$ cell population toward a predominance of $\mathrm{CD}^{+} \mathrm{T}_{\mathrm{EM}}$ and $\mathrm{T}_{\mathrm{EMRA}}$ cells, thereby accelerating changes seen with immunosenescence. Prior analysis of these trial populations at baseline additionally identified increased IFN $\gamma$ production in RRMM, largely from $\mathrm{CD}^{+} \mathrm{T}$ cells (23), which would be consistent with our observation of a predominance of $\mathrm{CD} 8^{+} \mathrm{T}_{\mathrm{EM}}$ and $\mathrm{T}_{\text {EMRA }}$ cells. The paucity of new thymic emigrants and a heavy reliance on homeostatic proliferation of oligoclonal $\mathrm{CD} 8^{+}$ $\mathrm{T}$ cells to reconstitute the $\mathrm{T}$ cell pool will likely significantly affect an individual's ability to respond to new or recall antigens, whether in the form of vaccination or infection. Analysis of the molecular biomarker p16 ${ }^{\mathrm{INK} 4 \mathrm{a}}$ (p16) suggested that ASCT induces molecular aging of $\mathrm{T}$ cells (37), providing further evidence of the detrimental effect of ASCT.
We acknowledge some limitations in our analysis including the restriction of $\mathrm{T}$ cell analysis to the $\mathrm{PB}$ compartment [although other studies have pointed to similarities in $\mathrm{T}$ cell populations from the $\mathrm{PB}$ and $\mathrm{BM}(23,38)]$, the superiority of newer technologies such as mass spectrometry to better identify canonical populations, and the low numbers of samples in the RRMM group.

Nevertheless, our findings are particularly relevant for the utility and production of autologous CAR-T cells in MM. It appears that CAR-T cell production is best achieved with relatively undifferentiated $\mathrm{T}$ cells, such as $\mathrm{T}_{\mathrm{N}}$ and stem cell memory subsets $(39,40)$. In mouse models of lymphoma, CAR$\mathrm{T}$ cells derived from $\mathrm{T}_{\mathrm{N}}$ and $\mathrm{T}_{\mathrm{CM}}$ cells were shown to be more efficacious than those from than $\mathrm{T}_{\mathrm{EM}}$ cells due to superior cytokine production of $\mathrm{CD} 4^{+} \mathrm{T}$ cells and cytotoxicity of $\mathrm{CD} 8^{+}$ $\mathrm{T}$ cells (41). Furthermore, the potency of CAR-T cell therapy is dramatically enhanced by generating $\mathrm{CD}^{+}$CAR-T cells from $\mathrm{T}_{\mathrm{CM}}$ cultured with $\mathrm{CD} 4^{+} \mathrm{T}$ cells. In humans, Garfall et al. (42) found that a higher frequency of $\mathrm{CD} 8{ }^{+} \mathrm{CD} 45 \mathrm{RO}^{-} \mathrm{CD} 27^{+} \mathrm{T}$ cells and a higher CD4:8 ratio at the time of leukapheresis for CAR-T production were the key factors associated with superior clinical outcome. Therefore, a CAR-T product generated from T cells from a heavily pre-treated, immunosenescent individual would be expected to be impaired. A practical approach in the clinic to maximize the effectiveness of a CAR-T cell product in MM patients could be to collect and store T cells prior to ASCT, before the shift in composition of the $\mathrm{T}$ cell population, when a higher number of naïve and stem cell memory $\mathrm{T}$ cells might be collected.

It was, however, interesting to note that our findings of an increase in the proportion of $\mathrm{CD}^{+}{ }^{+} \mathrm{T}$ cells with a $\mathrm{T}_{\mathrm{CM}}$ phenotype in LEN/DEX-treated RRMM (Figure 2C) were also mirrored in the QUIREDEX trial (LEN \pm DEX in high-risk smoldering MM) 
A

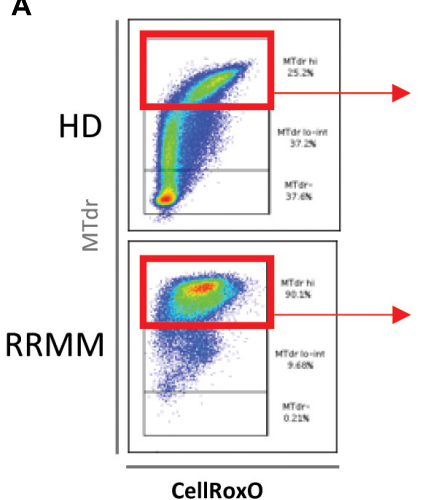

Representative histogram

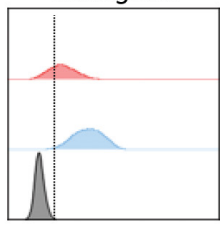

Negative control $\square$ Healthy donor $\square$ RRMM
C
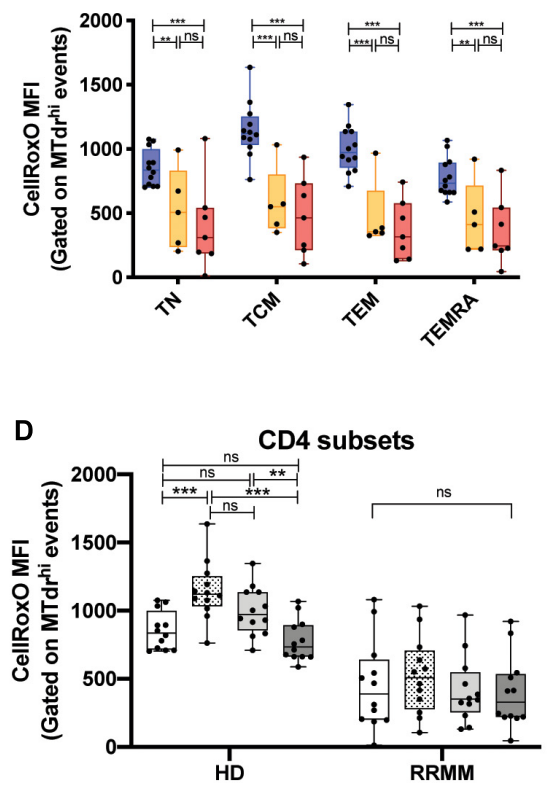

B

Reactive Oxygen Species

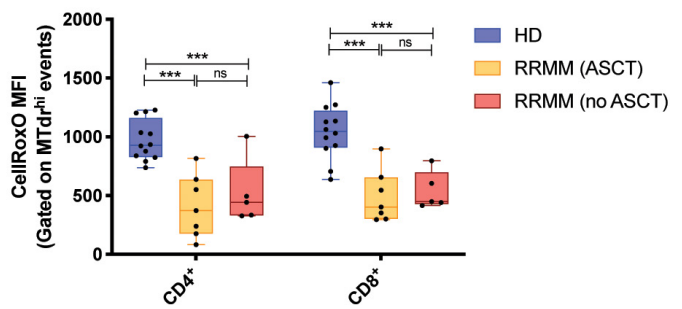

$\mathrm{CD}^{+}$
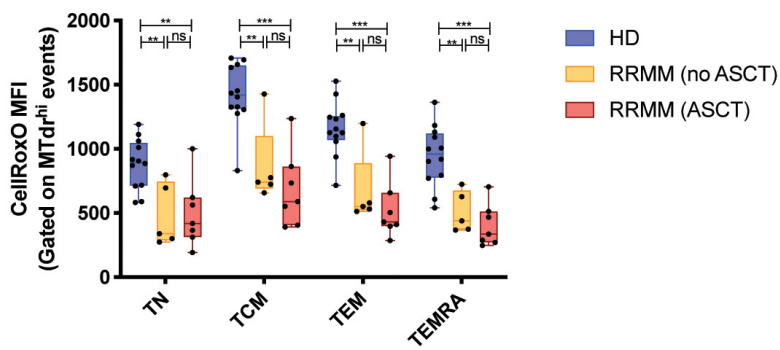

$\square \operatorname{RRMM}($ ASCT)

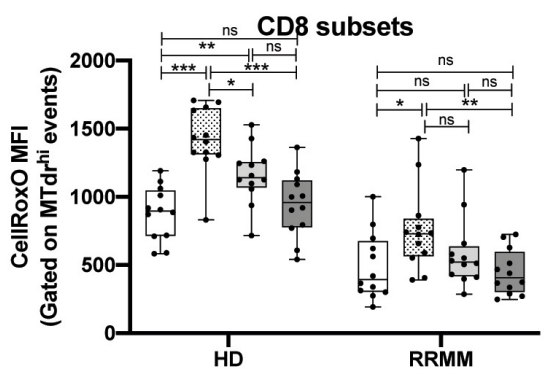

FIGURE 6 | Reactive oxygen species (ROS) levels in RRMM. (A) Gating strategy for assessment of ROS in CD4+ and CD8 ${ }^{+} \mathrm{T}^{+}$cells with high mitochondrial mass (MTdr hi cells), using geometric mean fluorescence intensity (MFI) of CellRox Orange (CellRoxO). (B) Box and whisker plots of CellRoxO MFI in CD4 ${ }^{+}$and $\mathrm{CD}^{+} \mathrm{T}^{-}$ cells from RRMM and HD. (C) Box and whisker plots of CellRoxO MFI in CD4 ${ }^{+}$and CD8 ${ }^{+} \mathrm{T}$ cell subsets from RRMM and HD. (D) Comparison of CellRoxO MFI in T cell differentiation subsets across RRMM (pooled) and HD. Study groups as described in Figure 1. Statistical significance in all figures was determined using multiple Student's $t$-tests with the Holm-Sidak method applied $\left({ }^{*} p<0.05,{ }^{* *} p<0.01,{ }^{* * *} p<0.001\right)$.

(43). This trial reported a significant increase in the proportion of $\mathrm{CD} 4{ }^{+} \mathrm{T}_{\mathrm{CM}}$ cells by cycle 9 of treatment and, moreover, $\mathrm{CD} 4{ }^{+}$ $\mathrm{T}$ cells were both functional in terms of cytokine production and proliferative as assessed by expression of activation and proliferation markers. It is not clear, however, whether this change is indicative of re-engagement of the immune system in disease control and/or is related to lenalidomide treatment, and we await the long-term outcome of this trial.

We also show that the frequency of $\mathrm{PD}^{+} \mathrm{CD} 4^{+} \mathrm{T}$ cells increases post-ASCT and in RRMM, particularly within the $\mathrm{CD}^{+}{ }^{+} \mathrm{T}_{\mathrm{CM}}$ cell subset (Figure 3 ), which would be expected to impede tumor surveillance and DC vaccination. In previous work, we demonstrated that the frequency of $\mathrm{T}_{\text {REGS }}$ increases post-ASCT (Supplementary Figure 5) and with LEN/DEX in
RRMM (44), which could upregulate PD-L1 expression on DCs. However, increased PD-1 expression can also indicate proliferation, as PD-1 is upregulated on initial T cell activation and its expression increases with sustained TCR signaling (45) or chronic antigen stimulation due to infection or tumor. To explore this possibility, further analysis of epitope specificity, TCR repertoire, and telomere length would be of interest. It is possible that a large proportion of these cells are CMV-specific, as oligoclonal expansions can develop in older humans (46), but it is also plausible that this population contains MM-specific $\mathrm{T}$ cell clones, the presence of which have been associated with long-term survival $(47,48)$.

Transcriptional and metabolic analyses of $\mathrm{CD} 4^{+}$and $\mathrm{CD} 8^{+} \mathrm{T}$ cells in RRMM showed significant increases in FAO transcripts 


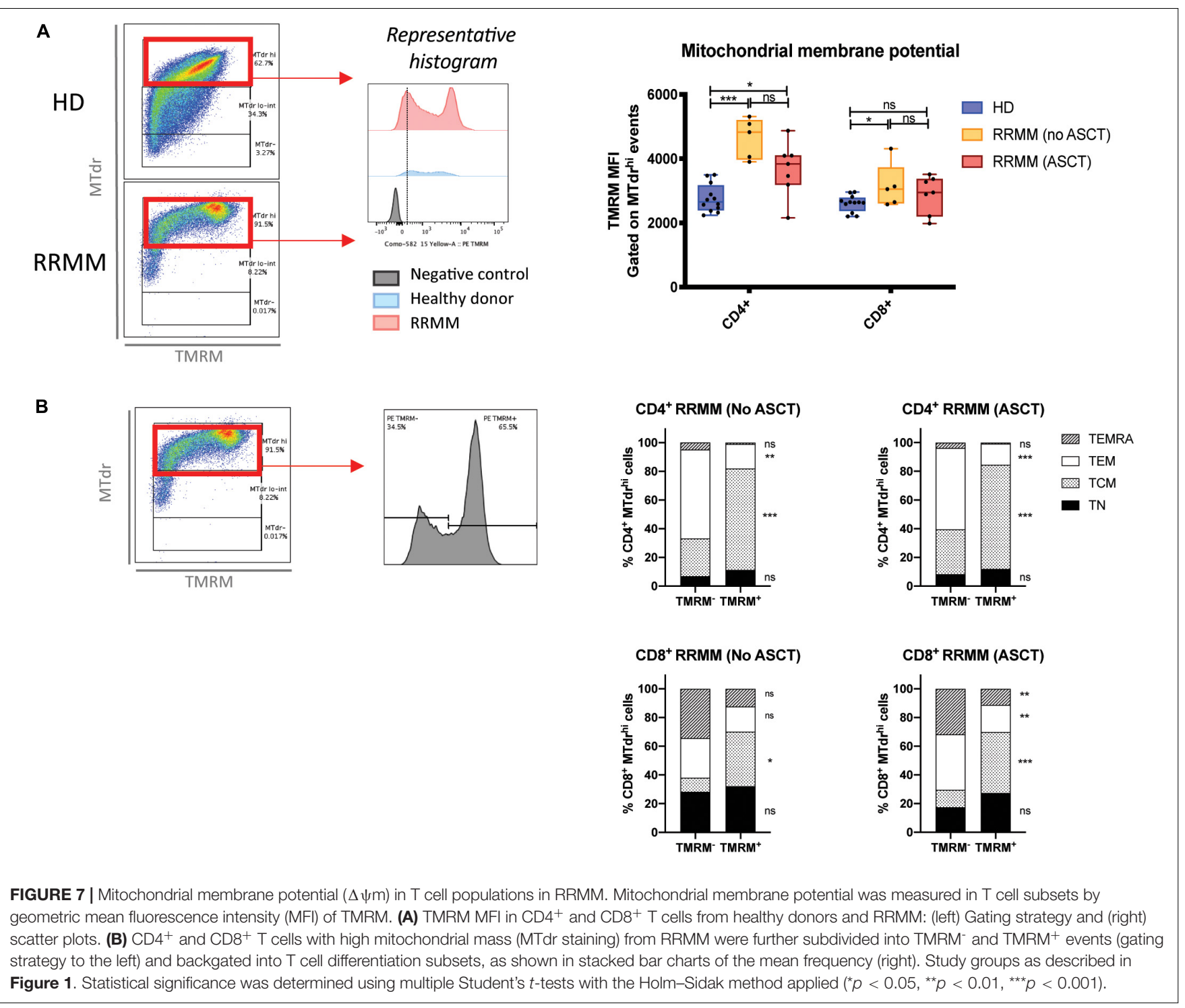

(Figure 4) and increased mitochondrial mass (Figure 5). Memory $\mathrm{T}$ cells are known to have higher mitochondrial mass and engage FAO for their energy requirements, while $\mathrm{T}_{\mathrm{N}}$ cells have low mitochondrial mass and low energy requirements (34). Accordingly, the shift in cell proportions after ACST, with a loss of $\mathrm{T}_{\mathrm{N}}$ cells and an increase in $\mathrm{T}_{\mathrm{CM} / \mathrm{EM}}$ cells, is likely to account for some of the increase in FAO transcripts and mitochondrial mass. However, it should be noted that an increase in mitochondrial mass was observed at all $\mathrm{T}$ cell differentiation states. This global increase could be driven by lymphopenia-associated IL-15 signaling, as IL-15 is known to promote CPT1a expression and FAO engagement and promote mitochondrial biogenesis $(49,50)$. Mitochondrial mass was highest in $\mathrm{T}_{\mathrm{CM}}$ cells and, notably, $\mathrm{T}_{\mathrm{N}}$ cells. This suggests that the remaining $\mathrm{T}_{\mathrm{N}}$ cells are not truly naive and they may have acquired some memory-associated metabolic characteristics during ASCT, likely from lymphopeniaassociated signals.
Given the increased mitochondrial mass in $\mathrm{T}$ cells in RRMM, the reduction in ROS levels was unexpected (Figure 6). A potential explanation for discordance between mitochondrial mass and ROS production is that the mitochondria that accumulate in RRMM $\mathrm{T}$ cells may be less metabolically fit. This is consistent with the relatively low $\Delta \psi \mathrm{m}$ that was observed in $\mathrm{CD}^{+} \mathrm{T}$ cells with RRMM (Figure 7A). This effect may again be driven by lymphopenia-induced IL15 signaling, as it was recently shown that effector $\mathrm{CD}^{+}$ $\mathrm{T}$ cells transferred into irradiated mice had increased mitochondrial content but lower $\Delta \psi \mathrm{m}$ compared with those transferred into IL-15-deficient irradiated mice (13). In contrast, RRMM CD4 ${ }^{+} \mathrm{T}$ cells exhibited elevated $\Delta \psi \mathrm{m}$ compared with HD but high $\Delta \psi \mathrm{m}$ associated with the $\mathrm{T}_{\mathrm{CM}}$ subset (Figure 7B), highlighting that $\mathrm{CD}^{+} \mathrm{T}_{\mathrm{CM}}$ remain a metabolically active subset. Clarification of the metabolic fitness of these cell subsets with further metabolic studies would be beneficial. Unfortunately, this was not feasible in this analysis 
due to the effects on mitochondria by lengthy cryopreservation of these samples and limited duplicate samples but would be important in future prospective studies.

\section{CONCLUSION}

Taken together, our findings show that the composition and metabolic profile of the $\mathrm{T}$ cell compartment shifts significantly over time in MM. This is likely a consequence of an interplay between aging, duration of disease, and cumulative treatment, but ASCT clearly has a dominant role. Given the inherent variability in these processes, the use of phenotypic and metabolic biomarkers to immunologically profile a patient at the time of clinical decision making will aid in directing and optimizing therapy for MM. Furthermore, if metabolic remodeling can be attenuated without reducing reconstitution after ASCT, it may better preserve functionality in $\mathrm{T}$ cell populations.

\section{DATA AVAILABILITY STATEMENT}

The raw data supporting the conclusions of this article will be made available by the authors, without undue reservation. The RNAseq data is accessible under accession number PRJNA658707 at https://www.ncbi.nlm.nih.gov/bioproject/PRJNA658707/.

\section{ETHICS STATEMENT}

The studies involving human participants were reviewed and approved by Peter MacCallum Cancer Centre. The patients/participants provided their written informed consent to participate in this study.

\section{REFERENCES}

1. Rajkumar SV, Dimopoulos MA, Palumbo A, Bladé J, Merlini G, Mateos M-V, et al. International myeloma working group updated criteria for the diagnosis of multiple myeloma. Lancet Oncol. (2014) 15:e538-48. doi: 10.1016/S14702045(14)70442-5

2. Röllig C, Knop S, Bornhäuser M. Multiple myeloma. Lancet. (2015) 385:2197208.

3. Turesson I, Velez R, Kristinsson SY, Landgren O. Patterns of multiple myeloma during the past 5 decades: stable incidence rates for all age groups in the population but rapidly changing age distribution in the clinic. Mayo Clin Proc. (2010) 85:225-30. doi: 10.4065/mcp.2009.0426

4. Harrison SJ, Quach H, Link E, Seymour JF, Ritchie DS, Ruell S, et al. A high rate of durable responses with romidepsin, bortezomib, and dexamethasone in relapsed or refractory multiple myeloma. Blood. (2011) 118:6274-83. doi: 10.1182/blood-2011-03-339879

5. Costa LJ, Brill IK, Omel J, Godby K, Kumar SK, Brown EE. Recent trends in multiple myeloma incidence and survival by age, race, and ethnicity in the United States. Blood Adv. (2017) 1:282-7. doi: 10.1182/bloodadvances. 2016002493

6. Herndler-Brandstetter D, Ishigame H, Flavell RA. How to define biomarkers of human T cell aging and immunocompetence? Front Immunol. (2013) 4:136. doi: 10.3389/fimmu.2013.00136

\section{AUTHOR CONTRIBUTIONS}

RC designed and performed the laboratory research, analyzed the data, and wrote the manuscript. KQ provided significant assistance with writing. SH, HQ, HP, and DR were principal investigators for the Litvacc and/or RevLite clinical trials. RK and DR assisted with the research design and editing of the manuscript. All authors contributed to the article and approved the submitted version.

\section{FUNDING}

This research was funded by the Leukaemia Foundation Australia and supported by the University of Melbourne, the Royal Melbourne Hospital, and the Peter MacCallum Cancer Centre. Bioinformatic analysis of the RNA-Seq data was provided by Jessica Chung at Melbourne Bioinformatics (University of Melbourne).

\section{ACKNOWLEDGMENTS}

We acknowledge the assistance of Dr. Sarah Gabriel and Prof. Axel Kallies at the Peter Doherty Institute for Infection and Immunity with the mitochondrial staining experiments. cDNA library preparation and RNA sequencing were performed by the Australian Genome Research Facility (Victorian Comprehensive Cancer Centre, Melbourne).

\section{SUPPLEMENTARY MATERIAL}

The Supplementary Material for this article can be found online at: https://www.frontiersin.org/articles/10.3389/fimmu. 2020.02153/full\#supplementary-material

7. Nikolich-Žugich J. Aging of the T cell compartment in mice and humans: from no naive expectations to foggy memories. J Immunol. (2014) 193:2622-9. doi: 10.4049/jimmunol.1401174

8. Williams KM, Hakim FT, Gress RE. T cell immune reconstitution following lymphodepletion. Semin Immunol. (2007) 19:318-30. doi: 10.1016/j.smim. 2007.10.004

9. Douek DC, McFarland RD, Keiser PH, Gage EA, Massey JM, Haynes BF, et al. Changes in thymic function with age and during the treatment of HIV infection. Nature. (1998) 396:690-5. doi: 10.1038/25374

10. Mackall CL, Stein D, Fleisher TA, Brown MR, Hakim FT, Bare CV, et al. Prolonged CD4 depletion after sequential autologous peripheral blood progenitor cell infusions in children and young adults. Blood. (2000) 96:75462. doi: 10.1182/blood.v96.2.754

11. Zhang X, Sun S, Hwang I, Tough DF, Sprent J. Potent and selective stimulation of memory-phenotype CD8+ T cells in vivo by IL-15. Immunity. (1998) 8:591-9. doi: 10.1016/s1074-7613(00)80564-6

12. Le Saout C, Luckey MA, Villarino AV, Smith M, Hasley RB, Myers TG, et al. IL-7-dependent STAT1 activation limits homeostatic CD4+ T cell expansion. JCI Insight. (2017) 2:e96228.

13. Xu A, Bhanumathy KK, Wu J, Ye Z, Freywald A, Leary SC, et al. IL15 signaling promotes adoptive effector T-cell survival and memory formation in irradiation-induced lymphopenia. Cell Biosci. (2016) $6: 30$. 
14. Klarquist J, Chitrakar A, Pennock ND, Kilgore AM, Blain T, Zheng $\mathrm{C}$, et al. Clonal expansion of vaccine-elicited $\mathrm{T}$ cells is independent of aerobic glycolysis. Sci Immunol. (2018) 3:eaas9822. doi: 10.1126/sciimmunol. aas 9822

15. Davenport B, Eberlein J, van der Heide V, Jhun K, Nguyen TT, Victorino $\mathrm{F}$, et al. Aging of antiviral CD8+ memory $\mathrm{T}$ cells fosters increased survival, metabolic adaptations, and lymphoid tissue homing. I Immunol Am Assoc Immunol. (2019) 202:460-75. doi: 10.4049/jimmunol.180 1277

16. Goronzy JJ, Li G, Yang Z, Weyand CM. The janus head of T cell aging autoimmunity and immunodeficiency. Front Immunol. (2013) 4:131. doi: 10. 3389/fimmu.2013.00131

17. Henson SM, Lanna A, Riddell NE, Franzese O, Macaulay R, Griffiths SJ, et al. p38 signaling inhibits mTORC1-independent autophagy in senescent human CD8(+) T cells. J Clin Invest. (2014) 124:4004-16. doi: 10.1172/jci7 5051

18. Lanna A, Gomes DCO, Muller-Durovic B, McDonnell T, Escors D, Gilroy DW, et al. A sestrin-dependent Erk-Jnk-p38 MAPK activation complex inhibits immunity during aging. Nat Immunol. (2017) 18:354-63. doi: 10.1038/ni. 3665

19. Harmer D, Falank C, Reagan MR. Interleukin-6 interweaves the bone marrow microenvironment, bone loss, and multiple myeloma. Front Endocrinol. (2019) 9:3397. doi: 10.3389/fendo.2018.00788

20. Joshua DE, Brown RD, Ho PJ, Gibson J. Comprehensive review. Clini Lymphoma Myeloma. (2011) 8:283-6.

21. Suen H, Brown R, Yang S, Ho PJ, Gibson J, Joshua D. The failure of immune checkpoint blockade in multiple myeloma with PD-1 inhibitors in a phase 1 study. Leukemia. (2015) 29:1621-2. doi: 10.1038/leu.2015. 104

22. Cooke RE, Koldej R, Ritchie D. Immunotherapeutics in multiple myeloma: how can translational mouse models help? J Oncol. (2019) 2019:18.

23. Cooke RE, Gherardin NA, Harrison SJ, Quach H, Godfrey DI, Prince M, et al. Spontaneous onset and transplant models of the Vk* MYC mouse show immunological sequelae comparable to human multiple myeloma. J Transl Med. (2016) 14:259.

24. Gherardin NA. Unconventional T Cells: from Basic Biology to Multiple Myeloma. Minerva Access. (2016). Available online at: http://hdl.handle.net/ $11343 / 59299$

25. Kay NE. Blood levels of immune cells predict survival in myeloma patients: results of an Eastern Cooperative Oncology Group phase 3 trial for newly diagnosed multiple myeloma patients. Blood. (2001) 98:23-8. doi: 10.1182/ blood.v98.1.23

26. Harrison SJ, Khot AS, Tsin T, Hsu AK, Chen K, Loudovaris M, et al. Low dose lenalidomide and dexamethasone induction followed by autologous transplantation in untreated patients with myeloma is associated with high response rates and preservation of CD8, but not CD4 or NK cellular immunity. Blood. (2011) 118:1862. doi: 10.1182/blood.v118.21.1862. 1862

27. Hsu AK, Quach H, Tai T, Prince HM, Harrison SJ, Trapani JA, et al. The immunostimulatory effect of lenalidomide on NK-cell function is profoundly inhibited by concurrent dexamethasone therapy. Blood. (2011) 117:1605-13. doi: 10.1182/blood-2010-04-278432

28. Hsu AK, Gherardin N, Quach H, Harrison SJ, Prince HM, Ritchie D. CD57+ NK CELLS ARE increased in patients with multiple myeloma and ARE primed effectors for ADCC, but NOT natural cytotoxicty. Neeson P, editor. Blood. (2013) 122:1904. doi: 10.1182/blood.v122.21.1904. 1904

29. Liu R, Holik AZ, Su S, Jansz N, Chen K, Leong HS, et al. Why weight? Modelling sample and observational level variability improves power in RNA-seq analyses. Nucleic Acids Res. (2015) 43:e97. doi: 10.1093/nar/ gkv412

30. Chung DJ, Pronschinske KB, Shyer JA, Sharma S, Leung S, Curran SA, et al. T-cell exhaustion in multiple myeloma relapse after autotransplant: optimal timing of immunotherapy. Cancer Immunol Res. (2016) 4:61-71 doi: 10.1158/ 2326-6066.cir-15-0055

31. Hallett WHD, Jing W, Drobyski WR, Johnson BD. Immunosuppressive effects of multiple myeloma are overcome by PD-L1 blockade. Biol
Blood Marrow Transplant. (2011) 17:1133-45. doi: 10.1016/j.bbmt.2011. 03.011

32. Kearl TJ, Jing W, Gershan JA, Johnson BD. Programmed death receptor-1/programmed death receptor ligand-1 blockade after transient lymphodepletion to treat myeloma. J Immunol. (2013) 190:5620-8. doi: 10.4049/jimmunol.1202005

33. Tkachev V, Goodell S, Opipari AW, Hao L-Y, Franchi L, Glick GD, et al. Programmed death-1 controls $\mathrm{T}$ cell survival by regulating oxidative metabolism. J Immunol. (2015) 194:5789-800. doi: 10.4049/jimmunol. 1402180

34. Man K, Kallies A. Synchronizing transcriptional control of T cell metabolism and function. Nat Rev Immunol. (2015) 15:574-84. doi: 10.1038/nri 3874

35. O'Neill LAJ, Kishton RJ, Rathmell J. A guide to immunometabolism for immunologists. Nat Rev Immunol. (2016) 16:553-65. doi: 10.1038/nri.20 16.70

36. Buck MD, O'Sullivan D, Pearce EL. T cell metabolism drives immunity. J Exp Med. (2015) 212:1345-60. doi: 10.1084/jem.20151159

37. Rosko A, Hofmeister C, Benson D, Efebera Y, Huang Y, Gillahan J, et al. Autologous hematopoietic stem cell transplant induces the molecular aging of T-cells in multiple myeloma. Bone Marrow Transplant. (2015) 50:1379-81. doi: 10.1038/bmt.2015.143

38. Kourelis TV, Villasboas JC, Jessen E, Dasari S, Dispenzieri A, Jevremovic $\mathrm{D}$, et al. Mass cytometry dissects $\mathrm{T}$ cell heterogeneity in the immune tumor microenvironment of common dysproteinemias at diagnosis and after first line therapies. Blood Cancer J. (2019) 9:72.

39. Crompton JG, Clever D, Vizcardo R, Rao M, Restifo NP. Reprogramming antitumor immunity. Trends Immunol. (2014) 35:178-85. doi: 10.1016/j.it. 2014.02.003

40. Sukumar M, Kishton RJ, Restifo NP. Metabolic reprograming of anti-tumor immunity. Curr Opin Immunol. (2017) 46:14-22. doi: 10.1016/j.coi.2017.03. 011

41. Sommermeyer D, Hudecek M, Kosasih PL, Gogishvili T, Maloney DG, Turtle CJ, et al. Chimeric antigen receptor-modified $\mathrm{T}$ cells derived from defined $\mathrm{CD} 8+$ and $\mathrm{CD} 4+$ subsets confer superior antitumor reactivity in vivo. Leukemia. (2015) 30:492-500. doi: 10.1038/leu.2015. 247

42. Garfall AL, Dancy EK, Cohen AD, Hwang W-T, Fraietta JA, Davis MM, et al. T-cell phenotypes associated with effective CAR T-cell therapy in postinduction vs relapsed multiple myeloma. Blood Adv. (2019) 3:2812-5. doi: 10.1182/bloodadvances.201900 0600

43. Paiva B, Mateos M-V, Sanchez-Abarca LI, Puig N, Vidriales M-B, LópezCorral L, et al. Immune status of high-risk smoldering multiple myeloma patients and its therapeutic modulation under LenDex: a longitudinal analysis. Blood. (2016) 127:1151-62. doi: 10.1182/blood-2015-10-66 2320

44. Quach H, Ritchie D, Neeson P, Harrison S, Tai T, Tainton K, et al. Regulatory $\mathrm{T}$ cells (Treg) are depressed in patients with relapsed/refractory multiple myeloma (MM) and increases towards normal range in responding patients treated with lenalidomide (LEN). Blood. (2008) 112:1696-1696. doi: 10.1182/ blood.v112.11.1696.1696

45. Chikuma S, Terawaki S, Hayashi T, Nabeshima R, Yoshida T, Shibayama $\mathrm{S}$, et al. PD-1-mediated suppression of IL-2 production induces CD8+ T cell anergy in vivo. J Immunol. (2009) 182:6682-9. doi: 10.4049/jimmunol. 0900080

46. Tu W, Rao S. Mechanisms underlying $\mathrm{T}$ cell immunosenescence: aging and cytomegalovirus infection. Front Microbiol. (2016) 7:2111. doi: 10.3389/fmicb. 2016.02111

47. Brown RD, Spencer A, Joy Ho P, Kennedy N, Kabani K, Yang S, et al. Prognostically significant cytotoxic $\mathrm{T}$ cell clones are stimulated after thalidomide therapy in patients with multiple myeloma. Leuk Lymphoma. (2009) 50:1860-4. doi: 10.3109/1042819090321 6804

48. Bryant C, Suen H, Brown R, Yang S, Favaloro J, Aklilu E, et al. Long-term survival in multiple myeloma is associated with a distinct immunological profile, which includes proliferative cytotoxic T-cell clones and a favourable 
Treg/Th17 balance. Blood Cancer J. (2013) 3:e148. doi: 10.1038/bcj.20 13.34

49. van der Windt GJW, Everts B, Chang C-H, Curtis JD, Freitas TC, Amiel E, et al. Mitochondrial respiratory capacity is a critical regulator of CD8+ T cell memory development. Immunity. (2012) 36:68-78. doi: 10.1016/j.immuni. 2011.12.007

50. O'Sullivan D, van der Windt GJW, Huang SC-C, Curtis JD, Chang C-H, Buck MD, et al. Memory $\mathrm{CD} 8(+) \mathrm{T}$ cells use cell-intrinsic lipolysis to support the metabolic programming necessary for development. Immunity. (2014) 41:75-88. doi: 10.1016/j.immuni.2014. 06.005
Conflict of Interest: The authors declare that the research was conducted in the absence of any commercial or financial relationships that could be construed as a potential conflict of interest.

Copyright (๑) 2020 Cooke, Quinn, Quach, Harrison, Prince, Koldej and Ritchie. This is an open-access article distributed under the terms of the Creative Commons Attribution License (CC BY). The use, distribution or reproduction in other forums is permitted, provided the original author(s) and the copyright owner(s) are credited and that the original publication in this journal is cited, in accordance with accepted academic practice. No use, distribution or reproduction is permitted which does not comply with these terms. 